\title{
REPRESENTAÇÕES DE CULTURA E COSTUME: O rURAL, O URBano e O faxinal.
}

\author{
Prof. Dr. Ancelmo Schörner \\ Prof. Dr, José Adilçon Campigoto'
}

\begin{abstract}
Resumo: Este artigo é parte de um estudo sobre, aplicações conceituais, e representações de cultura e de costume abstraídas de escritos referentes às relações entre: o campo e a cidade, o clima e o comportamento, o ambiente e o caráter, a história e o desenvolvimento regional. Os textos que serviram como fontes versam sobre o estado do Paraná, principalmente, a região Centro Sul, área de abrangência do sistema de faxinais. Nota-se que os escritos das décadas de 1960-70, quando lideranças políticas estaduais desencadearam diversas ações no sentido de afirmar as marcas culturais do Estado, incorporam e, às vezes, radicalizam concepções de cultura e costume adotados pelos sujeitos envolvidos no movimento de constituição da identidade paranaense, durante as décadas de 1930 e 1940. A tese comum aos dois períodos consiste em que o Paraná é a terra do progresso, donde a cultura é representada como produto do espaço urbanoindustrial, enquanto o costume é o que se reproduz no ambiente rural. Partimos da hipótese de que o uso desses termos, numa perspectiva linear e de progresso, pode implicar a desvalorização das realidades locais e principalmente dos povos tradicionais.
\end{abstract}

Palavras-chave: Representação; Costume; Cultura; Faxinal.

Abstract: This article is part of a study about conceptual applications, and representations of culture and usage abstracted from writings on the relationship between: rural and urban areas, the climate and behavior, the environment and nature, history and regional development. The texts that served as sources are writings on the state of Parana, especially, the Central South area, which contain the system "faxinais". Note that the writings of the decades of 1960-70, when local leaders did several actions in order to assert the state's cultural identity, they adopted and sometimes they radicalized notions of culture and usage before used by the subjects involved in the movement of constitution the identity of Paraná, during the 1930's and 1940’s. The view common to both periods is that the Paraná

I Professores do Departamento de História da Universidade Estadual Centro-Oeste do Paraná/UNICENTRO.E-mail para contato: ancelmo.schorner@terra.com.bre ja.cam.pi@hotmail.com. 
is the land of the progress, where the culture was represented as a product of the urban-industrial reality, while the common usage and custom is what is produced in the rural environment. We start from the hypothesis that the use of these terms, in a linear and "progressive" perspective, may lead to the depreciation of local realities and especially of the original people.

Key-words: Representation; Custom; Culture; Faxinal.

Na região Centro-Sul do Paraná, entre as décadas de 1960 e 80, produziuse uma série de escritos referentes à realidade regional, em que se associam os termos cultura e costume a expressões como civilização, cidade, campo, sociedade, etnias, povo, desenvolvimento, atraso, educação e barbárie. Dita produção pode ser considerada como um conjunto de representações que caracterizam os sujeitos, classificando-os segundo o espaço em que habitam e o conhecimento que possuem. Na perspectiva aqui adotada, as representações do social são evidências significativas para a escrita da história, uma vez que situam no tempo os sujeitos que as produzem. Cabe salientar, porém, que não se trata, apenas de mapear os conceitos utilizados pelos autores, porque então a tarefa se esgotaria no ato de encontrá-los e relacioná-los às teorias a que pertencem. Tal procedimento será realizado, em parte, visando ampliar a compreensão das fontes, mas o escopo deste artigo será mais amplo.

Parte-se do pressuposto da teoria das representações de que todo conceito é uma representação, donde os conceitos relativos ao social podem ser tomados como representações sociais. No entanto, agregamos que, nem todas as representações construídas socialmente implicam as mesmas características dos aparatos conceituais, principalmente, quando consideramos os conceitos, como é o caso aqui, nos seus aspectos funcionais de descrição, classificação, organização e antevisão dos fenômenos. As representações de cultura e costume são tomadas, aqui, como a forma pela qual o vivido é representado no texto.

Podemos pressupor, de início, que tais representações associam-se, de certa forma, ao movimento historiográfico ocorrido na primeira metade do século XIX, quando, conforme Pesavento:

O espírito romântico produziu historiadores preocupados em escrever histórias nacionais, que fossem atrás da captura do espírito do povo, da alma das nações, que procurassem os heróis com grandes feitos e que registrassem a saga da construção de cada Estado, a demonstrar que o germe da identidade nacional já estava presente naquele tempo das origens, com os pais fundadores. ${ }^{2}$ 
É possível que esse empenho dos românticos tenha criado certa correspondência entre algumas acepções de cultura e a idéia de identidade nacional, com aplicações no âmbito dos recortes regionais e locais, como seria o caso dos intelectuais ligados aos movimentos de construção das identidades estaduais, no Brasil de meados do século XX. Em outras palavras, é bem plausível partir do pressuposto de que, pelo menos no campo de influência desse dito romantismo ${ }^{3}$, os termos cultura e costume tornaram-se recorrente na identificação, classificação, definição e construção de tais identidades. Nesse caso, associados à perspectiva do progresso e da linearidade histórica, implicam a função de estabelecer recortes, suprimindo-se a radialidade, uma das exigências fundamentais a qualquer conceito. Por exemplo, assim como na perspectiva linear não se considera um concerto de música clássica como um costume ocidental, dificilmente se afirmaria, como veremos adiante, que plantar no toco (sem arar a terra) faz parte de cultura cabocla ou faxinalense. Podemos notar, então, que em nosso horizonte de compreensão ${ }^{4}$, não há equivalência entre este dois termos, mas, em muitos casos, a ausência de um equivale perfeitamente à existência do outro. Talvez o caso mais emblemático seja a perspectiva do evolucionismo antropológico, em que costume e tradição são concebidos como resíduos de um tempo passado na cultura presente. Partimos da hipótese de que o uso desses termos, numa perspectiva linear e de progresso, pode implicar a desvalorização das realidades locais e principalmente dos povos tradicionais.

Os textos selecionados para esta investigação foram escritos por historiadores, poetas, médicos, agrônomos e memorialistas locais. Trata-se de material referente à região de Irati $^{5}$ e ao Estado do Paraná, principalmente, produções versando sobre as relações entre o espaço rural e o ambiente urbano.

É o caso de um desses escritos produzidos no ano de 1978, para as comemorações do septuagésimo aniversário dessa cidade. Nele, incluiu-se certo diagnóstico do governo estadual a respeito da região em que Irati está localizada. ${ }^{6} \mathrm{O}$ editor selecionou a parte de documento oficial em que algumas parcelas do território paranaense - a área do alto e do médio Tibagi e a do Iguaçu - são descritas como

[...] regiões com características estruturais semelhantes $e$ que vêm perdendo posição relativa no contexto econômicosocial do Estado. A economia de tais regiões apresenta-se pouco dinâmica, assumindo, freqüentemente, o caráter de subsistência, apesar da existência de centros urbanos importantes nessas áreas. O governo deseja promover o equilíbrio regional, pela incorporação de regiões, atualmente, deprimidas, ao processo de desenvolvimento, bem como pelo desenvolvimento integrado das regiões dinâmicas. ${ }^{7}$ 
A cidade que estava para comemorar setenta anos de existência localizase nesse espaço, oficialmente caracterizado como deprimido. O editor da revista comemorativa, portanto, aderiu ao diagnóstico, mas sugeriu que os enunciados oficiais consistiam em provocações dirigidas às lideranças políticas locais. A esses sujeitos caberia a tarefa de modificar o quadro em que se dizia encontrar a cidade elevada à categoria de Vila pela Lei Estadual de $n^{\circ}$. 716, de 02/04/1907.

De qualquer forma, passados setenta anos, a antiga vila era representada como parte de uma região estagnada, sem energia, sem vitalidade, desprovida do suposto dinamismo característico de outros confins do estado. As causas de tal impotência foram apresentadas, em forma de poema, na mesma revista comemorativa, sob o mote a seguir: "nós Irati, povo dos anos setenta e dos setenta anos...”. Na segunda estrofe, de um conjunto de vinte e quatro, o autor, que é também o editor afirma que a cidade atravessou

[...] os ciclos do mate, da madeira e da agricultura. Nossa economia permaneceu fundamentada na terra. Estamos sendo vencidos por uma ideologia que sempre combatemos. Sem saber, cumprimos o anseio básico do integralismo, o que há de mais retrógrado nesse chamado fascismo tupiniquim, qual seja, a hostilidade absoluta à civilização urbano-industrial. ${ }^{8}$

Os versos tratam da economia, da estagnação e de certo comportamento considerado como estigma local. Trata-se da total hostilidade à civilização. O autor assevera que a causa de tal aversão ao mundo urbano esta na permanência de alguma crença, enfim, algum resíduo inconsciente do 'fascismo tupiniquim'. Essa conduta política local seria a causa da economia fundamentada na agricultura, modelo econômico responsável pela estagnação da cidade.

Pode-se dizer que essa oposição entre a economia agrícola e a civilização urbano-industrial esboça a cisão básica sobre a qual se assenta o conceito de cultura utilizado no poema. A agricultura é apresentada como o oposto da indústria, esta considerada como propulsora da civilização. Desse modo, a economia 'fundamentada na terra' significará barbárie.

Esse jogo de opostos no qual se faz referência ao integralismo pode ser considerado como resultante de um longo debate a respeito da identidade brasileira e regional. Segundo a tese defendida por Geraldo Leão Veiga de Camargo, há um paradoxo na constituição das bases teóricas utilizadas pelos intelectuais paranaenses no que diz respeito à elaboração da identidade estadual. O caboclo, um dos elementos centrais na discussão sobre cultura brasileira,

Ora visto como criatura pura e feliz, símbolo da fusão das culturas européias e de uma visão idílica do indígena, ora como elemento corrompido, prova do atraso e degeneração resul- 
tante da miscigenação entre duas raças puras, ele foi por muito tempo tema de discussões científicas e obras literárias e plásticas. ${ }^{9}$

Camargo contrapõe a figura do caboclo elaborada por Plínio Salgado à de Monteiro Lobato, o que nos parece bem ilustrativo para a compreensão dos enunciados de Orreda. Plínio foi intelectual e político com relativa influência no Estado do Paraná. Considerava o tipo caboclo como uma espécie de síntese da identidade nacional, voltado para os valores locais, e, portanto, em princípio, avesso aos processos de internacionalização. O caboclo ‘prova do atraso' foi figura notabilizada nas obras de Monteiro Lobato, que mais tarde deixou de considerá-la como produto do meio, mas criatura degenerada devido às condições em que se encontra. Uma das evidências de que esta polarização atravessava os debates e as tese dos escritores, memorialistas e intelectuais paranaenses, principalmente no auge do chamado movimentos paranista, é apresentada ainda por Camargo, referindo-se a Rocha Pombo. O autor fala das repercussões relativas uma das mais famosas obras de Lobato, afirmando que:

O sucesso retumbante de Urupês provoca uma celeuma de onde 'emergem vários tipos humanos que se contrapunham ao Jeca Tatu'. Moraes cita Edgard Cavalheiro para lembrar do Mané Chique-Chique, 'rocha viva da nacionalidade’, ‘domador do deserto', 'desbravador da Amazônia', e que se 'o Norte opunha ao Jeca essa hercúlea e perfeita encarnação de herói, o Sul, pela pena de Rocha Pombo não ficava atrás: lá havia o Jeca Leão, também o oposto do Tatu, figura cheia de virtudes e de nenhum defeito'. ${ }^{10}$

A região da qual falava Orreda, na década de 1970, apoiando-se num debate que teve seu auge nos anos 40, não é propriamente caracterizada como área de cultura cabocla. Algo bastante peculiar numa área caracteristicamente apontada como espaço de imigração e colonização eslava, não fosse pela tese da 'caboclização' dos eslavos, que veremos mais à frente. Note-se, também, que a figura do jeca, nos moldes do integralismo, é projetada sobre a cidade e não especificamente sobre o espaço rural.

A resistência à civilização, apontada pelo autor do mote "nós Irati, povo dos anos setenta e dos setenta anos...", talvez por isso mesmo, aparece como condição transitória. Ainda no poema, a população local se vislumbra como

Potencial humano sem igual com extraordinária capacidade de trabalho, harmonia e tenacidade [...]. Produto étnico da união do índio, português, espanhol, holandês, alemão, polonês, ucraniano, sírio, austríaco, italiano e outras nacionalidades, começamos a formar uma nova raça de gente forte e inteli- 
gente, sobretudo solidária, capaz de sentir o encanto do vale do sol que existe no outro lado da montanha. ${ }^{11}$

Assim, o autor delineia certa situação deprimente, provocada por alguma aversão à civilização, e que poderá ser superada por meio da miscigenação étnica, não raramente pensada como antídoto à misoginia. Trata-se, também, de instar os leitores a tomar alguma atitude porque, conforme o texto, todos estamos “[...] deixando o tempo passar [...] sem perspectiva histórica, demonstramos não ter consciência do presente ou do futuro, despreocupados com o desenvolvimento sócio-econômico da comunidade" ${ }^{12}$ A metáfora do vale do sol deve referir-se ao tal desenvolvimento da sociedade urbano-industrial. O sol é um dos símbolos marcantes da poética paranista, compondo o brasão de armas do Estado, emblema proposto por Romário Martins. Para o autor, o astro “...seria o símbolo americano por excelência; nele, desde a mais remota antiguidade da Ameríndia, os povos do Novo Mundo homenageiam a fonte da vida.". ${ }^{13} \mathrm{O}$ vale do sol é o contraponto do espaço ocupado pela raça que se forma.

Essa estirpe nova deve emergir no conjunto dos habitantes da região sobre a qual se projeta a imagem de sujeitos inativos, que permitem o 'livre fluir do tempo'; um quadro composto por indivíduos despreocupados e inertes, meio entorpecidos pela rotina. Representação controversa, bastante enraizada no âmbito da historiografia paranaense, e que está vinculada ao movimento de constituição da identidade estadual. Tais enunciados apareceram de forma contundente, por exemplo, no História psicológica do Paraná, escrito por Davi Carneiro, no início da década de $1940^{14}$. Ali, encontram-se os rudimentos das imagens evocadas no poema de Orreda ${ }^{15}$.

Os paranistas, como diz Luis Cláudio Soares de Oliveira,

Influenciados pelo cientificismo e o positivismo, tendências bastante presentes na virada do século XIX para o XX, criaram, em maio de 1900, em reunião nas dependências do Clube Curitibano, o Instituto Histórico e Geográfico Paranaense. Este instituto contou, na sua primeira diretoria provisória, com Romário Martins, Sebastião Paraná e Ermelino de Leão. ${ }^{16}$

O Instituto pode ser considerado como uma das peças fundamentais na consolidação do que se chamou de história regional do Paraná. Além dos três historiadores componentes da primeira diretoria provisória, reunia intelectuais influentes em termos de produção do conhecimento relativo ao Estado do Paraná. Em 1948, passou por uma remodelação, vindo a chamar-se Instituto Histórico Geográfico e Etnográfico Paranaense do qual tanto Orreda quanto Carneiro foram membros. Na época da remodelação do Instituto, Carneiro, mais ativo, já havia publicado o controverso livro História psicológica, referindo-se, primeira- 
mente, ao que considerou como duas graves deformidades dos paranaenses contemporâneos seus. Conforme o autor:

O primeiro desses defeitos é o retraimento excessivo, uma espécie de misantropia que chega às raias de doença. É ele que nos impede de dizer entre estranhos, por vergonha, por medo, por falta de personalidade ou de valor aquilo que pensamos (certo ou errado) e que nos impede, mais ainda, de proceder, com medo que se nos diga que o que fazemos é feio, é impróprio ou errado. O segundo defeito, talvez ainda mais grave, que o anterior, é a complacência exagerada. ${ }^{17}$

O paranaense é representado por Carneiro como sujeito acometido de aversão aos homens, ou seja, de repulsa à vida em sociedade. A impressão que se tem é de que a misantropia pareceu-lhe intrínseca à população do Estado. Sensação corroborada quando se vê que o autor recorreu à metáfora do corpo doente para esboçar a amplitude daquilo que avaliava como uma moléstia grave. Para Carneiro (1943), a melancolia representava um fenômeno muito próximo ao estado de achaque. Carneiro afirma que o conteúdo de seu o livro foi objeto de inquérito policial, considerado, em primeira instância como uma afronta às autoridades políticas originárias de outros estados. Era o período em que o governo Getúlio nomeara os interventores. No caso do Paraná, tratava-se de Manuel Ribas, pontagrossense que governou como interventor, pela segunda vez, desde 1937 a 1945. O governador não era adventício, mas outra acusação consistia em que o material promovia o regionalismo. Carneiro foi considerado inocente no Tribunal de Segurança Nacional. O processo foi arquivado e o material, publicado em forma de livro.

Os enunciados sobre o desânimo e a tristeza, no entanto, foram retomadas, após três décadas, para classificar as regiões do Alto e do Médio Tibagi e Iguaçu: áreas deprimidas. Pode-se aventar que aquelas noções da década de quarenta ‘migraram' para as páginas de um documento oficial, elaborado por uma equipe composta por membros do Governo Estadual e da Universidade Federal do Estado do Paraná. As mesmas representações repetem-se no poema de Orreda, sendo a intertextualidade evidente.

Podemos, também, propor que os escritos de Carneiro ofereciam sustentação para os vaticínios a respeito da depressão regional, pois neles, os paranaenses da década de 1940 haviam sido descritos como sujeitos

[...] retraídos, medrosos de ridículo onde... não poderiam parecer, desde logo tímidos, e maledicentes por invejosos em certo grau, das vitórias alheias, displicentes com as coisas mais sérias e prestando atenção a nonadas, tais são os seus piores defeitos. ${ }^{18}$ 
O autor partia do princípio de que esses supostos traços do comportamento social local eram a causa da pouca influência exercida pelos representantes políticos estaduais no cenário nacional; mas interessam, para o presente estudo, principalmente, as representações construídas pelo autor. Essas dizem respeito ao comportamento social e, à primeira vista, estariam desvinculadas da temática deste artigo, isto é, as representações de cultura e costume. Tal impressão, no entanto, se desfaz inteiramente com a leitura do capítulo intitulado como $O$ meio moldando a alma. Ali, afirma-se a tese de que o modo de ser paranaense seria o produto de vários fatores, sendo preponderantes o meio físico e a sociedade que fornece a educação e a cultura aos habitantes da região.

Assim, a influência do meio geográfico é apontada como o fator determinante na organização de uma sociedade sempre que a cultura desse grupo não está suficientemente desenvolvida. Nesses casos, o meio físico exerce a influência maior, uma vez que práticas sociais novas vão sendo adotados em substituição às tradições debilitadas, exatamente, por falta de cultivo. A tese parece fundamentar-se no possibilismo geográfico de Vidal de la Blache ou no determinismo cultural de Lewis Henry Morgan, mas segundo Brasil Pinheiro Machado, o discurso paranista tem essa particularidade desde a origem. Para Machado, nas reflexões de Romário Martins,

[...] o fundamento da tematização tem como núcleo teórico a afirmação de que a história do Paraná, tal como ele a enfoca, é a história de uma comunidade, isto é, de um grupo humano nas suas relações com o meio geográfico ... O campo e a floresta, não somente decidiram de nossa existência como de nossa índole. Nos primeiros tempos fomos criadores e tropeiros e todas as nossas antigas cidades do planalto tiveram origens nessas atividades dos nossos antepassados. O nosso homem do campo, porém, encontrou na floresta mais fácil exploração de riquezas e se fez extrator de erva-mate e, depois, também de madeiras. ${ }^{19}$

Seja como for, Carneiro escreveu a História psicológica a partir desse mesmo axioma, indicando que, desde os começos, o ambiente teria sido o fator determinante na compleição da alma paranaense. A constituição desse povo, assim descrito, teria iniciado em Paranaguá com a vinda de “[...] alguns homens rudes, desejosos de fazer fortuna, talvez chefiando combatentes e degradados [...]. Essa gente era sem dúvida rude, guerreira, áspera”. ${ }^{20}$

Nesse quadro 'genealógico' da cultura local, como se vê, a imagem é de uma geração composta por pessoas selvagens, toscas, de caráter duro, ríspido e severo, gente de difícil cultivo moral ou intelectual, ignorante e de pouca inteligência. Esse povo da origem, segundo Carneiro (1943), europeus e mestiços, 
teria se adaptado ao meio, rico em elementos favoráveis ao seu estilo de vida, adequado para que se fixassem à beira-mar. Tal estadia, apesar de breve, teria provocado, de alguma forma, certa melhoria no caráter daquela gente que fez a travessia da serra do mar, durante o século XVI; e, assim, povoou-se o primeiro planalto. Alojada no novo ambiente, tal população desenvolveu o comodismo.

Descer para o litoral, segundo o autor, seria tarefa das mais penosas, assim como transportar o produto do trabalho. Além disso, não valeria a pena transportar qualquer produto ao porto, uma vez que, nada se poderia exportar por conta da política metropolitana. Então, na figura esboçada por Carneiro, "a tendência foi, desde logo, à inércia”. ${ }^{21}$ Assim, cultivou-se a disposição à preguiça, à indolência, ao torpor, ao estado de repouso, na origem da formação do povo paranaense.

O autor segue explicando que, por causa disso, nessa 'primeira chapada geográfica', somente se produziria o necessário para o consumo dos habitantes locais, dos moradores das vilas e dos pequenos povoados ou, então, das fazendas dispersas pela região. Nesse lugar, acrescenta, o gado se reproduzia espontaneamente, implicando a ociosidade dos peões e fazendeiros, que praticamente só movimentavam-se, além do basicamente necessário, nas épocas de guerra aos índios, de rodeios e da matança das reses. O ambiente rural teria prevalecido sobre as tradições. O meio produziu o vício que não cessou de se reproduzir.

Tal disposição apática se reproduziu, segundo Carneiro, durante o século XVII, no Paraná, “como uma moléstia endêmica” num ambiente propício. Os pinheiros teriam oferecido o pinhão e as florestas, frutos silvestres, tais como guabirobas, araçás, pitangas, cerejas e jabuticabas. Então, desde que se descobriram algumas vantagens da exploração da erva mate, a partir do século XVII, nada mais teria faltado a esta população.

Carneiro acrescentou a tese de que aquele modo de vida dos primórdios estendeu-se para os Campos Gerais. ${ }^{22}$ Região coberta pelas campinas, constituída por solos pobres a ponto de não oferecer condições para iniciativas comerciais ou industriais. Até mesmo a agricultura estaria relegada à falta de empreendimentos consideráveis. O ambiente, mais uma vez, explicaria a conduta do habitante típico dessa região, "fazendo dele espontaneamente um lerdo, um preguiçoso". ${ }^{23}$ Segundo a perspectiva da História psicológica, esses sujeitos broncos e inertes, mas com outras qualidades, formaram o núcleo embrionário da população regional. Mais do que moldar as atitudes de algumas gerações, o meio teria, desde o início, imprimido sua marca original no caráter do povo paranaense. Tal idéia seria retomada para classificar outros espaços e outras manifestações culturais no âmbito do território estadual tais como os vales do Tibagi e do Iguaçu e o sistema de faxinais. ${ }^{24}$ 
O autor fora pessimista em relação à imigração. Seus escritos nos levam a considerar que concebe a lerdeza e a preguiça como um sinal, talvez, permanente, porque nem mesmo o contato com outros povos teria provocado alguma mudança significativa nesse estado de coisas. Assim,

A experiência das imigrações com diferentes raças não modificou o feitio primitivo, pois os paranaenses de hoje somos (sic.) preguiçosos como os do século XVII e os do século XIX, vistos por Saint Hilaire. As almas são as mesmas, afeitas à contemplação, à maledicência, ao comodismo inerte e amorfo. ${ }^{25}$

Então, mais do que um comportamento isolado numa época passada, o dito traço comportamental seria detectável por toda a história do Estado, pelo menos até a década de 1940 .

Na parte que trata dos Campos Gerais, o autor introduziu uma discussão sobre as relações entre o meio físico e o comportamento, englobando, finalmente, a questão da cultura. Escreveu que neste lugar, no início, havia "[...] comida abundante, mas só isso [...]". Tratava-se de campos "sáfaros, insuficientes para dar vida fácil pela fortuna que exigisse iniciativa, em comércio, indústria ou sequer lavoura”. Comida fácil num campo indócil, rude e inculto, gerando a inércia que se perpetua. O meio molda a alma "[...] quando a cultura de determinado núcleo social não é superior, desenvolvida e polimorfa...”. ${ }^{26} \mathrm{Na}$ História psicológica de Davi Carneiro, cultura significa o grau de conhecimento acumulado ou adquirido por um povo, é tradição cultivada, o que implica o trabalho humano, ou seja, a produção simbólica.

As teses sobre as relações entre o meio ambiente e o desenvolvimento cultural reaparecem, de certa forma, nas páginas da citada revista comemorativa ao sexagésimo aniversário de Irati. Ali, encontra-se escrito, em forma de legenda, sob uma foto da cidade, que "[...] não apenas produto de suas localizações estratégicas, as cidades são, também, o resultado do trabalho [...]”. ${ }^{27}$ Como se vê, as cidades são consideradas como 'obras' dos lugares em que se situam, mas, ao mesmo tempo, como produtos das tarefas que seus habitantes se propõem a fazer.

A relação intrínseca entre a cidade e o meio, no entanto, reeditou-se, explicitamente, nos textos elaborados por José Maria Orreda e de outro escritor iratiense contemporâneo seu, o poeta Foed Castro Chamma. Em Notas para a ecologia de Irati, Chamma ${ }^{28}$ aponta que

[...] existe uma relação inegável entre o homem e a natureza que o cerca, advindo de seu convívio uma realidade que bem se pode apontar como fonte de análise e interpretação da realidade iratiense a partir de sua configuração geográfica, 
incrustada a cidade como está, num declive, com um panorama que se limita a extensas áreas de vegetação, nobre vegetação de uma natureza exuberante. Tal fato dispõe seus habitantes a uma permanente sensação de segurança e bemestar $[\ldots] .{ }^{29}$

Chamma partia do pressuposto de que

[...] todos os dados para o aferimento de determinada comunidade, dentro de um critério de análise de seus valores éticos, sociais e culturais, estão estreitamente vinculados à sua realidade geográfica, uma vez que a natureza humana tende sempre a reagir ao meio que a circunda, dele decorrendo o caráter do indivíduo e a própria formação da cultura ${ }^{30}$

A cultura e os valores são considerados, pelo poeta, como produtos do meio geográfico circundante. É do meio que decorrem as atitudes individuais e coletivas. Por ser a máquina produtora do caráter individual e grupal o meio será fator explicativo para compreensão das situações locais e para a construção de identidades regionais de que o paranismo será a expressão maior em termos de Estado. Como diz Oliveira:

Essa busca de identidade e mesmo a construção de referências teve uma grande retomada nos anos 70, quando Jaime Lerner assumiu a prefeitura da capital paranaense e, posteriormente, na década de 90, o governo do estado. Intervenções urbanísticas ou simplesmente paisagísticas continuaram sendo feitas pensando nessa criação de identidade cultural. ${ }^{31}$

De fato, Chamma escreveu em 1967, no mesmo ano em que publicava seu livro de poemas Labirinto. Dois anos mais tarde, lançou a obra Ir a ti. O Labirinto inaugurou, conforme André Seffrin, uma das fases do poeta que "passa a apresentar um compasso de extração neo-simbolista”. ${ }^{32}$

Esse movimento estético, é bom frisar, encontra-se na base dos arranjos teóricos paranistas porque Romário Martins, um de seus maiores promotores,

[...] teve sua formação e atividades anteriores calcados no simbolismo, e uma atividade inicialmente hostil à participação de imigrantes europeus por considerá-los, no contexto da Curitiba do final do século XIX e início do XX, como elementos perturbadores, estranhos à constituição do que entendia como a miscigenação ideal do homem paranaense. A ligação com os aspectos românticos do simbolismo lhe permite adaptar as teorias sociológicas e científicas sobre as influências do meio físico e da raça para elaborar uma descrição mítica das especificidades paranaenses, desvinculada da imagem mulata 
e tropical do brasileiro como visto por outros modernistas como Mário de Andrade. Contra esta idéia e a partir da introdução inevitável dos ádvenas nas relações sociais locais, Martins acaba por incorporar sua contribuição, vista agora como uma vantagem. ${ }^{33}$

O enunciado de que os elementos e informações para a avaliação, a medição ou o cotejamento de qualquer grupo social vinculam-se à sua realidade geográfica, todavia, indica a complexidade da questão, porque se está falando de grupos sociais diferentes. $\mathrm{O}$ autor considera o fenômeno cultural como produto do meio, mas o objeto que é o ponto de partida de sua análise não se encontra no distante tempo das origens, nem se limita à região, como é o caso do texto de Carneiro.

Chamma escreveu que, a partir do esquema por ele adotado, poderia:

Focalizar, dentro da realidade brasileira, o comportamento dos diversos agrupamentos humanos em categorias distintas, advindo mesmo um caráter específico em cada região com reflexos em todos os fatores da vida, sem excluir mesmo a própria vida da cidade que se desenvolve com suas ruas e calçadas sob o influxo de sua condição topográfica ${ }^{34}$

Apresenta, na oportunidade, o movimento concretista como ilustração, que, no Brasil, resultou na criação de dois grupos com características distintas: um em São Paulo e, outro, no Rio de Janeiro. Conforme Chamma, o primeiro produziu arte poética capaz de captar o que seria a índole do homem paulista: dinâmica e racional, centrada na ordem comercial, no elemento da propaganda e na cultura de massas. Os cariocas, no entanto, teriam mostrado sua rebeldia ao movimento, acrescentando-lhe aspectos psicológicos e subjetivos, o que lhes rendeu o título de neoconcretistas. Ainda, para exemplificar, apela ao caso mineiro. A realidade geográfica teria feito dos habitantes daquele Estado um povo introvertido, inteligente e com propensão à resolução de problemas metafísicos. Podemos supor que os exemplos apresentados pelo autor não foram escolhidos por acaso. Tratase de um movimento artístico-literário, automaticamente vinculado a certo conceito de cultura, que se produz ou se remodela nos centros urbanos, diga-se que eram os considerados como mais importantes do país, na época. Uma representação começa a esboçar-se: a cultura é produto que se processa no meio urbano.

Irati, então, é apresentada como centro urbano situado num declive, rodeado por extensas áreas de vegetação, paisagem que imprimiria nos seus habitantes a sensação perene de segurança e bem estar. Tal sentimento de garantia e conforto seria a causa do "lento, mas seguro, progresso urbano" local. ${ }^{35}$

Chamma fala de progresso, enquanto Carneiro aponta a inércia. O deslocamento que parece haver em termos de enfoque deve-se não somente às diferenças 
de contexto dos objetos analisados pelos autores, quer sejam, os antigos moradores do segundo planalto e dos Campos Gerais, e os habitantes de Irati da década de 1970. Mas devemos notar que, Carneiro refere-se ao espaço rural enquanto Chamma vislumbra o mundo urbano. O autor de Notas pra a ecologia de Irati apontava que a pequena cidade se revelaria, em breve, como importante centro econômico e cultural. Nesta época, vivia-se o clima do chamado milagre brasileiro, fazendo sentido esses prognósticos sobre uma nova era de progresso, já anunciada pelos fundadores do movimento paranista desde, pelo menos, a década de $1930 .^{36}$

Sempre vinculando os objetos de sua análise aos aspectos geográficos, Chamma esboçou um quadro das chamadas “feições singulares” da área urbana de Irati, que

[...] a distingue das demais cidades do interior brasileiro pelo traçado urbano, com todas as ruas muito largas, todas muito bem calçadas, os passeios com mais de dois metros de largura, produzindo a sensação de bem estar que se traduz pelos efeitos de claridade, amplitude, arejamento, raramente experimentado em qualquer outro lugar do interior brasileiro... Sua arquitetura... Como acontece em todas as cidades do país, que se renovam apresentando súbita visão panorâmica de sua grandeza, apresenta um saudável coeficiente de força, vitalidade, energia, haurido de sua economia, de sua indústria, de seu comércio, de sua lavoura, que se manifestam através de residências suntuosas por todo o curso da rua Dr. Correia, da Rua Marechal [...]. ${ }^{37}$

Na descrição, os pressupostos teóricos se mantêm, mas o quadro se inverte porque se refere ao espaço urbano: não mais a inércia da área rural, habitada por rudes aventureiros, preguiçosos e maledicentes; não mais a região deprimida dos homens lerdos repousando em campos sáfaros. A cidade do declive, cercada pela mata, apresenta-se com lugar da arquitetura moderna, à qual o comércio adere, "mesclando o humano e o natural". A "grandeza" de tal urbe "nasce da situação geográfica privilegiada”, sendo que a economia e o ensino estariam agregando os esforços da população em torno da criação de um centro cultural e urbano. Tais concorrências aparecem como sinais claros da vida cultural ativa, apontada pelo autor.

A cidade é ainda representada como lugar constituído por algum "patriarcalismo altruísta e abnegado” dos empresários locais e dos pioneiros da educação escolar, cuja ação resultaria no desejo de criar uma faculdade de filosofia ${ }^{38}$. Representa-se, também, a cidade como lugar da inspiração poética, de trovadores amadores e parnasianos, de artistas engajados no teatro amador e dos clubes de pais e mestres, que se espalham para o interior. A cidade seria, então, "quase 
um centro de efervescência cultural”, espaço da informação, da produção literária que se estende de figuras como o velho trovador da vila São João, ao romancista local Bráulio Zarpellon, José Maria Orreda, Olga Gyezynski Zeni, Antonio Lopes Junior e Maria Luiza Hessel; recinto da pintura que retrata sua própria beleza. Formosura que "se estende por todos os limites do município".

A imagem da ebulição cultural que irradia para todos os recantos do território municipal pode ser vinculada à metáfora do sol, parecendo-nos fútil e casual, mas no jogo das representações sobre a cultura e os costumes, sobre o rural e o urbano, adquire significado relevante. Evidencia que, na perspectiva do autor e do paranismo, a cultura é como um raio de luz que irradia do núcleo urbano para a área rural, o que completa o quadro do meio rural atrasado, estagnado e inculto, debruado nos textos de Carneiro.

Chamma não se deteve a descrever apenas a área urbana. Expôs também as características do meio rural que circunda a cidade, iniciando como que no final de um percurso sobre a área urbana. Então,

Fora dos limites urbanos, a cidade reedita a antiga placidez de uma vida campestre, com seus colonos, seus sitiantes, seus fazendeiros, inaugurando a paisagem matinal através da tranqüila presença de rebanhos, como se uma página viva se abrisse e nos colocasse sob um céu de profecias e cânticos sagrados. ${ }^{39}$

O excerto reproduz e refaz, de alguma forma, a 'imagem da quietude' característica desse discurso sobre a vida campestre. O sossego, a letargia, o estado sonolento dos colonos, sitiantes e fazendeiros reaparece, como que emergindo das páginas escritas por Carneiro. A atitude fleumática dos rebanhos, ruminando na modorra, e "o tempo verde, claro" evocam a inércia, a lerdeza e a preguiça rudimentar, talvez, imposta pelo meio; caracteres que, na perspectiva desses autores, serão eliminados pela irradiação da cultura urbana. Eis a profecia, o cântico sagrado e o milagre referido nos textos. Para eles, trata-se de ações encampadas por algumas instituições urbanas, porque o seu produto se irradia por intermédio das escolas, dos clubes, do rádio, da televisão e da atitude dos "patriarcas da cidade", alguns que até assumem cadeira no conselho municipal. Estes plantam uva em suas chácaras localizadas nas cercanias da cidade e, mesmo, no interior do perímetro urbano; assim, espalham a civilização e a tecnologia. Então, a cultura aparece como o contraponto dos costumes conservados na área rural e que serão substituídos.

Tais presságios evidenciam-se noutro texto, escrito pelo mesmo autor, em julho de 1966. Trata-se de matéria sobre uma convenção dos clubes 4 S, ocorrida naquele ano, na cidade de Irati. Conforme o texto, 
[...] a realidade agrária brasileira começa já a se ressentir de uma ação que irá modificar substancialmente o panorama econômico e cultural do país em futuro muito próximo. Trata-se de um trabalho do governo visando uma orientação racional para o agricultor na assimilação de fatores científicos que permitam o desenvolvimento de suas culturas agropecuárias fora daquele temor sacramentado por um culto que vem de idades mitológicas, quando Ceres era evocada, e eram rendidos sacrifícios em favor da deusa para a proteção das colheitas. ${ }^{40}$

Tais clubes dedicavam-se, principalmente, a ensinar técnicas de economia doméstica, de higiene básica ou preventiva, de cooperativismo e de artesanato. ${ }^{41}$ Para Chamma, esta seria a assimilação de fatores científicos que permitiriam o desenvolvimento da agropecuária, a irradiação da cultura até os lugares onde habitavam os agricultores.

O autor refere-se à cultura agropecuária que, em sua opinião, deve ser modificada por fundamentar-se num "temor sacramentado por certo culto oriundo de idades mitológicas, quando a deusa Ceres era evocada, por meio de sacrifícios, para que protegesse as colheitas”. Portanto, emprega o termo cultura para referir-se ao espaço rural, mas a 'orientação racional' que o 'centro urbano irradia', segundo o prognóstico, será modificada substancialmente. A noção de cultura, nesse caso, vincula-se à tecnologia, o conhecimento racional que se contrapõe a certas práticas, para ele, oriundas das idades mitológicas. A referência ao culto de Ceres não se dá por acaso, afinal trata-se de uma divindade agrícola e Chamma refere-se à área rural de uma região povoada por caboclos e imigrantes ucranianos e poloneses, considerados, veremos adiante, como povos extremamente religiosos. Também conhecida como Demeter, é a divindade da terra cultivada ${ }^{42}$, das colheitas, das estações do ano e do trigo, uma das plantas que simbolizam 'regiões agrícolas'. Segundo antigas narrativas mediterrâneas, teria ela feito várias e longas viagens, em companhia de Dionísio, para ensinar os seres humanos a cultivarem a terra e a dominarem as técnicas do plantio, ${ }^{43}$ mas cabe ressaltar que Ceres era cultuada pelas camadas populares do império romano. ${ }^{44}$ Então, no quadro descrito por Chamma, os agricultores da região de Irati estão associados às camadas mais pobres da população brasileira e vinculados a antigas práticas ‘anacrônicas’. Os costumes dessa gente serão concebidos como produtos de uma visão mitológica do mundo, conservada na área rural.

Certamente o poeta não haveria encontrado vestígios de culto à divindade greco-romana entre os agricultores paranaenses. É mais provável que Chamma estivesse referindo-se a algumas práticas culturais locais tais como a benção das lavouras ou a consagração das águas dos rios, realizadas, por exemplo, no faxinal ${ }^{45}$ do Itapará ${ }^{46}$. Esse faxinal, modo de organização dos agricultores da região 
para o uso comum da terra, é emblemático para o estudo em andamento aqui, porque expressa a relação entre a cultura local e a eslava. Conforme Orreda:

A colonização da região teve início em 1908, com a chegada dos imigrantes ucranianos e poloneses que formaram a vila, entrando por Prudentópolis. As terras, 7.016 hectares foram divididas em 300 lotes... Logo após a chegada dos imigrantes, alojados em um grande barracão e casas de taquara, efetuadas as primeiras plantações... Em 1917, os colonos trabalharam abrindo, em troca de alimentação, a estrada rumo à vila de Irati. Mais tarde, o governo auxiliou novamente com sementes e ferramentas. Apenas em 1917 começou-se a utilizar o arado na região. Plantava-se no toco... ${ }^{47}$

Uma das peculiaridades do Itapará consiste em que os imigrantes assentados não seguiram o modelo geral da colonização na região Sul do Brasil. Seguindo o modelo utilizado pelos caboclos, delimitaram uma área comum para a criação de animais. ${ }^{48}$ Conforme depoimento recolhido por Joceli Novak ${ }^{49}$, a benção da lavoura segue o rito ucraino e acontece na época em que as sementes já germinaram. Antes da celebração da missa, os fiéis e o padre, em procissão, dirigem-se para uma das plantações próximas ao templo e inicia-se o cerimonial. O rito repete-se nos quatro cantos da área plantada, com a finalidade de proteger as demais áreas cultivadas na região. A intenção é de que se tenha boa colheita.

A consagração das águas, no entanto, envolve maiores detalhes.

Um dia antes, os rapazes reuniam-se para fazer a limpeza das valas. Tiravam a sujeira trazida pelas enchentes, de dentro do rio. No dia seis de janeiro, a luz de velas enfeitava a noite. Às três da madrugada, o padre Bendito Mennik e a procissão iam cantando e rezando, até o rio. O local do benzimento variava. Algumas vezes era perto do moinho. Outras, perto da ponte. O padre apagava as três velas nas águas do rio. Fazia isso três vezes. Rezava uma missa, depois enchiam as vasilhas de água e iam para casa. Nos nove dias da novena as águas eram sagradas e ninguém podia tomar banho nem lavar roupas no rio ${ }^{50}$.

Os ritos da benção da lavoura e dos rios, como vimos, vinculam-se às práticas culturais dos imigrantes ucranianos e poloneses, vindos para essa região no final do século XIX e início do XX. Tais práticas desses moradores da área rural foram consideradas ao modo de resistências, resíduos de épocas passadas, pois se supunha que o acesso à cultura implicaria a ruptura e abandono das 'visões mitológicas' mantidas pelos nativos e trazidas pelos imigrantes.

Já vimos que Davi Carneiro era da opinião de que a presença dos imigrantes não teria modificado aquele dito "feitio primitivo" dos paranaenses; 
mas isso não é tudo. O agrônomo Newton Sponholz, por exemplo, radicalizou, ainda, essa idéia. Em texto escrito, no início da década de 1970, para a comemoração do centenário da emancipação política do município de Imbituva, também localizado na sub-região dos pinhais, ${ }^{51}$ indica que, além de não exercerem influência sobre o modo de vida local, os eslavos teriam adotado o sossego, a letargia e o estado sonolento dos paranaenses nativos.

O autor constrói seus argumentos julgando como expressiva

[...] a porcentagem do nosso tipo característico, o caboclo, com sua tendência para o trabalho extrativo, quer nas serrarias ou na extração do mate. O caboclo sofreu o impacto do declínio destas atividades na região, pois não tem como o europeu, a tradição do trabalho e do cultivo da terra e sim, o costume de extrair as dádivas da natureza. ${ }^{52}$

É nesse ponto de contato entre etnias, eslavos e caboclos, que se evidenciam as aplicações dos termos cultura e costume, que viemos enunciando desde o começo. O europeu (eslavo) perde sua 'cultura' em função dos 'costumes' caboclos. O eurocentrismo é flagrante, mas a coisa poderia ser posta ao inverso; mas pensar o caboclo como povo que tem apenas costumes pode ser considerado como parte de uma longa tradição.

Veja como este sujeito "típico" descrito por Sponholz assemelha-se aos primeiros habitantes do Estado, representados na obra de Carneiro. Os textos a que o agrônomo recorre para sustentar suas afirmações são de autoria de Monteiro Lobato. Então, o caboclo aparece como tipo humano identificado pelos produtos que vende nas feiras, tais como cocos de tucum, frutas silvestres, orquídeas, ou, no máximo, artefatos de taquara, peneiras, cestinhas, samburás, tipitis, gamelas e colheres de pau. A imagem é de um grupo humano praticante do extrativismo, que levou ao esgotamento dos recursos naturais locais. O empobrecimento decorrente de tal economia, segundo Sponholz, possivelmente, conduziu muitos desses nativos ao hábito do consumo abusivo do álcool. O autor escreve que "talvez, nossa dadivosa ecologia tenha influído no seu caráter". ${ }^{33}$ Logo em seguida, ainda, declara que "[...] afora a tendência extrativista formada pelas próprias condições do meio, é o caboclo bastante inteligente”. Portanto, no quadro apresentado pelo autor, também o meio físico moldara o caráter e o comportamento dos caboclos, grupo social que teria exercido forte influência sobre o modo de vida adotado pelos imigrantes eslavos vindos para a região.

Como se vê, algumas idéias expressas na História psicológica tornam-se mais contundentes em A terra e o homem no sul do Paraná: problemas e perspectivas, de Sponholz. No momento, concentremo-nos nas afirmações sobre a chamada "caboclização do imigrante”. Tal fenômeno consistiria em que os 
imigrantes vindos para esta região, principalmente os poloneses e ucranianos, teriam abandonado "muitas técnicas importadas de seu país, diante de certas condições desfavoráveis do nosso meio" e assimilado "[...] práticas primitivas comuns entre nós: a queimada, as simpatias e outras". ${ }^{54} \mathrm{O}$ termo costume tornou-se, agora, equivalente à 'práticas primitivas', por oposição à técnica, saber característico do velho continente, mas não da Europa rural.

Sponholz tentou explicar as razões desse fenômeno resultante do contato das etnias que lhe parece uma espécie de regressão cultural do europeu. Escreveu que poloneses e ucranianos constituem os grupos étnicos mais significativos a imigrarem para a região dos pinhais. Trata-se de mais de trinta e cinco mil pessoas a se estabelecerem nesta 'província', entre os anos de 1892 e 1910. Argumenta o autor que, nesta mesma época, a Polônia encontrava-se sob o jugo da Rússia, da Áustria e da Prússia, países que procuravam manter o domínio, negando a instrução aos povos subjugados. A estratégia utilizada consistia em "impedir o desenvolvimento cultural dos oprimidos, dificultando-lhes a educação e, em conseqüência, o discernimento e a capacidade de pensar, para mais facilmente se utilizarem dos seus trabalhos braçais". ${ }^{55}$ Cultura é, portanto, o grau de conhecimento acumulado e que se desenvolve por meio da educação, como veremos, da escolarização. É, ainda, meio de libertação, uma vez que desenvolve a capacidade de pensar e discernir.

Assim, segundo o escrito de Sponholz, os ucranianos da Galícia, que era uma região rural ocupada pela Polônia, foram submetidos à mesma estratégia de poder. A administração austríaca era hostil aos camponeses e tal oposição resultou em que "a Galícia possuísse, senão a mais, pelo menos uma das mais arcaicas estruturas agrárias européias”. ${ }^{56}$

Para o autor, tais fatores marcaram profundamente a formação social dos imigrantes povoadores da região dos pinhais. Os poloneses e ucranianos eram laboriosos, pacíficos e trabalhadores, mas "sem condições para o desenvolvimento pelas características intrínsecas de sua formação". ${ }^{57}$ Tratava-se, pois, de sujeitos sem instrução, e que, ao aqui chegarem, faltou-lhes infra-estrutura "[...] desde implementos até escola”. Além "[...] do baixo nível cultural”, ${ }^{58}$ eram grupos sociais marcados pela experiência da submissão a regimes despóticos e pela marca de uma religiosidade arraigada.

A história deste povo (ou se poderia dizer a formação da sua alma) seria a causa das dificuldades, então, encontradas pelo agrônomo ao tentar "[...] motivá-los, impulsioná-los para o progresso, torná-los crentes em novos planos, fazêlos aceitar técnicas e conhecimentos, enfim organizá-los em comunidade." ${ }^{59}$

Na mesma descrição, os ucranianos são representados como grupo, na maioria, católico do rito oriental ou ortodoxo. Os poloneses, por sua vez, contra- 
riando a tendência geral dos povos eslavos, teriam adotado o catolicismo romano. Conforme a exposição do autor, os poloneses seriam mais apegados a associações religiosas do que a qualquer outro tipo de organização social, uma vez que a paróquia era, na Europa, o centro da vida social desses imigrantes e continuou sendo aqui. Na terra de origem estiveram sob controle cultural. Na região dos pinhais, teriam 'adotado os costumes caboclos', que, por sua vez, tinham os hábitos determinados pela influência do meio geográfico, leia-se, o ambiente rural.

A descrição do cotidiano rural nos moldes acima apresentados foi corroborada no texto de Orreda, produzido no final da década de setenta, sobre o mencionado distrito de Itapará. Fundado em 1920, é o mais distante do núcleo urbano de Irati e sua colonização foi iniciada em 1908, como dissemos

[...] logo após a chegada dos imigrantes, alojados em um grande barracão e casas de taquara [...]. Plantava-se no toco, como ainda hoje se faz em diversas áreas do distrito, em terrenos a pique [...]. Apesar da prosperidade inicial [...]. Sem qualquer espécie de assistência, decaindo a produção agrícola, a população isolando-se e dispersando-se foi sendo vencida num empobrecimento progressivo e pelas doenças endêmicas. (ORREDA, 1978, p. 21-22)

Trata-se de outra história narrada em estilo ‘trágico': uma derrota imposta pelo meio. Um descuido em relação à assistência por parte das autoridades competentes. As técnicas de plantação, ou seja, a cultura não evoluiu. O costume prevaleceu, pois ainda, planta-se no toco ${ }^{60}$. A produção decaiu, a população isolou-se, dispersou-se, empobreceu e adoeceu. A expressão "foi sendo vencida" leva o leitor, que desconhece a região, a imaginar que a povoação tenha desaparecido completamente.

O distrito de Itapará, no entanto, subsistiu. Trata-se de uma área de faxinal e seu espaço de abrangência atinge várias localidades. ${ }^{61}$ De fato, a cultura faxinalense não se enquadraria na estética do progresso, nem teve espaço no simbolismo romântico paranista. Não poderia ser considerada como manifestação cultural, uma vez que a cultura não é tida como produto específico do espaço rural. Assim, essa organização típica dos camponeses da Região dos Pinhais permaneceu à margem dos textos sobre história da região e do Estado do Paraná, mesmo daqueles escritos que tratavam especificamente das áreas de faxinal.

O texto, talvez, mais ilustrativo sobre o 'modo de vida inculto produzido pelo meio ambiente rural' encontra-se num artigo elaborado pelo chefe do Centro de Saúde de Irati, no ano de 1968. Era o médico Lourival Luiz Fornazzari, que resolveu realizar um inquérito parasitológico devido à quantidade de indivíduos provenientes do distrito de Itapará, portadores de anemia. Iniciou-se a investiga- 
ção sobre as condições ambientais e sócio-econômicas do lugar. O trabalho fundamentou-se num tipo de literatura que vinculava as doenças e as necessidades médicas das populações ao habitat, às instituições sociais e ao meio de vida. $\mathrm{O}$ meio agora não é mais simplesmente geográfico e sim sócio-ambiental. No texto resultante da averiguação encontra-se a descrição do local e da população ali existente. Itapará,

[...] situa-se em um planalto bastante acidentado, no sopé da Serra da Esperança. A vegetação é secundária, constituindose quase exclusivamente de capoeiras, pois o terreno é intensamente lavrado, persistindo pequenos capões de mato junto dos mananciais... A população do distrito é estimada em 3.000 pessoas, na sua maioria descendentes de ucranianos e poloneses, todos agricultores, fazendo raras exceções, alguns comerciantes [...]. O número de indivíduos de outros grupos étnicos é insignificante. Os produtos cultivados são: batata inglesa, milho, feijão, trigo, arroz, centeio, fumo, cebola e alho. As verduras e as frutas são raras. Criam-se galinhas e suínos sem métodos, sendo reduzidíssimo o gado vacum. São extremamente religiosos, conservando os costumes e as crendices herdadas dos ancestrais e algumas adquiridas em nosso meio [...]. O índice de alfabetização é pequeno [...]. ${ }^{62}$

Como se vê, a descrição segue a mesma lógica dos textos até aqui examinados. A área rural é representada como o lugar do empobrecimento progressivo e das doenças endêmicas, das estruturas agrárias arcaicas, sem condições para o desenvolvimento. É o lugar da 'caboclização do imigrante'. Os descendentes de poloneses e ucranianos teriam abandonado boa parte das técnicas importadas de seus países em favor de "práticas primitivas" como a queimada e plantar no toco.

Conforme a imagem resultante do diagnóstico, o distrito/faxinal é rodeado, quase exclusivamente, pela capoeira, ao contrário do centro urbano cercado de exuberante vegetação, consoante à imagem apresentada por Chamma. No meio do matagal vivem esses sujeitos imbuídos de uma 'religiosidade supersticiosa' herdada dos antepassados, que na visão de Sponholz, explica-se recorrendo à história desses grupos apegados a associações religiosas mais do que a outro tipo de organização social. Tais sujeitos, então, teriam conservado 'antigos costumes e crendices' e copiado outras tantas.

O diagnóstico da equipe de saúde refere-se, também, às condições de moradia, apontando que as habitações foram feitas de

[...] madeira de pinho, algumas cobertas de tabuinhas e outras de telha, com três ou quatro cômodos. Geralmente assoalhadas, a maioria apresentando chão de terra batida na cozinha. 


\begin{abstract}
Algumas caiadas, uma minoria pintada a óleo, com janelas envidraçadas e outras sem pintura. Resíduos e detritos jogados porta a fora. Não encontramos privadas na região, exceção feita às habitações de comerciantes. As dejeções são depositadas a céu aberto. A água utilizada para os diversos fins provêm de olho d'água [...]. Os animais domésticos - aves, porcos e cães - encontram-se soltos ao redor da casa. Tanto adultos como crianças andam descalços e a higiene pessoal deixa muito a desejar. A alimentação, em grande parte amilácea, pobre em proteínas animais e lipídeos. Os varões, de maneira geral, fazem uso de bebidas alcoólicas e do tabaco, sob a forma de cigarro de palha e cachimbo. Geralmente trabalham para um colono proprietário de terra em regime de empreitada ou alugando-as para o plantio, não colhendo quase sempre o suficiente para o sustento da própria família. ${ }^{63}$
\end{abstract}

A descrição desliza das condições de moradia para os ditos "costumes", certamente, porque tais atitudes tenham efeitos mais visíveis no âmbito da saúde. Uso de bebidas alcoólicas e do tabaco, andar sem calçados, descuido com a higiene e, por fim, a criação de animais às soltas, que é a característica básica do sistema de faxinais.

Como se evidenciou no texto de Fornazzari a expressão geralmente usada para caracterizar as práticas, as tradições, as relações que os habitantes da área rural estabelecem com o mundo, com a natureza e o sobrenatural "costumes e as crendices herdadas dos ancestrais”. O espaço não urbanizado é então representado como lugar em que a cultura está ausente, o que se expressa pelo analfabetismo e pela baixa produção de alimentos.

Para ir concluindo, nos textos estudados até aqui, a oposição entre a economia agrícola e a civilização urbano-industrial esboça a cisão básica sobre a qual se assenta os conceitos de cultura e costume. A agricultura é apresentada como o oposto da indústria, esta considerada como propulsora da civilização. A economia 'fundamentada na terra', por vezes, representará a barbárie. Parte-se da idéia força de que a sociedade fornece a educação e a cultura, mas quando a cultura de determinado núcleo social não é suficientemente desenvolvida, o meio ambiente determina a organização social. Cultura, nessa perspectiva, significa o grau de conhecimento acumulado ou adquirido por um povo.

A tese de que o meio geográfico circundante é a máquina produtora do caráter individual e da cultura parece estar no fundamento de todos os textos estudados. Então, uma cultura capaz de sobrepujar a influência do meio rural forçosamente seria produzida nos núcleos urbanos. A noção de cultura vinculase, assim, à tecnologia e ao conhecimento racional que se contrapõe a certas práticas tidas como oriundas das idades mitológicas. A cultura é produto do nú- 
cleo urbano e se irradia para a área rural, o que remete às imagens do atraso, da estagnação e da situação inculta presentes nos textos, até mesmo, dos mais românticos paranistas.

Por vezes, a cultura cabocla é considerada como um conjunto de práticas primitivas que se contrapõem ao que seria o grau de conhecimento acumulado no mundo urbano e que se desenvolve por meio da educação, ou melhor, da escolarização. Considerada como meio de libertação, uma vez que desenvolve a capacidade de pensar e discernir, teria sido negada aos eslavos que migraram para a região dos Pinhais. Eles, oriundos de regiões rurícolas, consideradas como arcaicas, foram assentados em áreas não urbanas, o que perpetuou a reprodução dos 'costumes'. Passaram a viver, em certos casos, rodeados pelo matagal, sempre imbuídos de uma 'religiosidade supersticiosa' herdada dos antepassados que se explica recorrendo à história pregressa.

Assim, as conexões estabelecidas entre a cultura, costume e o meio ambiente, nos textos de Sponholz, Orreda, Chamma e Fornazzari, nos remetem às teses dos paranistas, principalmente à Historia psicológica de Davi Carneiro. Os participantes deste movimento político do início do século XX, que uniu várias lideranças locais, exerceram larga influência na produção escrita sobre o Paraná. Como diz Oliveira,

Os nomes dos intelectuais e escritores paranaenses vivem se repetindo nessa virada do século XIX para o XX. Eles são referências na literatura, na política e nos estudos científicos, além de serem os responsáveis pela tentativa de formulação e fixação de uma personalidade própria do Paraná, em todos os sentidos. (OLIVEIRA, 2005, p. 29)

Suas atividades estenderam-se por, pelo menos meio século, resultando em obras que, em pouco tempo, repercutiram sobre as interpretações e compreensões relativas ao Estado. Tal movimento pode ser compreendido por sua vinculação às mudanças ocorridas na implantação do regime republicano no Brasil. A modificação do regime, segundo vários estudiosos do assunto, provocou intenso movimento de construção de identidades, tanto para a nação como um todo, quanto para as diversas realidades regionais. Mas o que importa aqui é a base teórica do republicanismo no âmbito do que significam a cultura e o progresso.

Luiz Fernando Lopes Pereira, por exemplo, aponta que a atitude básica na qual se fundamentaram tais construções seria a fé incondicional na ciência, no progresso, na técnica e o conseqüente empenho na eliminação de práticas consideradas como características dos sistemas mitológicos. A cultura cabocla, em certos aspectos, será alvo desta política de depuração. Basta referir a forma pela qual os caboclos foram tratados durante o conflito do Contestado. ${ }^{64}$ 
O paranismo é considerado como parte dessa articulação mais ampla, apresentando algumas características particulares: "seu positivismo e anticlericalismo, marcas profundas tanto dos políticos como dos intelectuais paranaenses, de novo incluindo os simbolistas, também contribuirá para esta visão científica e laica da sociedade, em oposição ao mito e à monarquia". ${ }^{65}$

O culto da técnica e a fé na ciência encontram-se, pois, na base daqueles enunciados sobre idades mitológicas, práticas primitivas, baixo nível cultural, misantropia, aversão à sociedade, presentes nos textos estudados até aqui. $\mathrm{O}$ conjunto se traduz na convicção de que as irradiações culturais originam-se nos centros urbanos em direção ao ambiente inculto, ao espaço do 'costume' que é o campo. Tal antinomia era recorrente entre os paranistas, o que resultou num conjunto de imagens sobre a positividade do progresso urbano e da agricultura moderna em oposição à agricultura de subsistência.

As imagens contidas nos textos da década de 1940 foram, pode-se dizer deslocadas no espaço e no tempo, quando evocadas no relatório oficial do Estado. Foram transpostas para as regiões do Alto e Médio Tibagi e Iguaçu, e transferidas para as décadas de sessenta e setenta. O modo de conceber as relações entre o meio e a cultura gerou as imagens da 'região deprimida'; então, essas figuras circularam nos textos das revistas comemorativas à fundação dos municípios de Irati e Imbituva.

O meio físico, o comportamento, o caráter dos caboclos, assim como o 'baixo nível cultural' e as 'crenças' dos imigrantes eslavos, passaram a ser representados como fatores que levaram a região dos pinhais à decadência, iniciada logo depois do breve surto de desenvolvimento, alcançado no auge da exploração da erva mate e da madeira. O cenário em que se desenrolam tais acontecimentos, por exemplo, é descrito por Sponholz ${ }^{66}$ como ambiente "do empobrecimento rural", "situação estagnada" e "lugar em que as famílias rurais vivem em estado crítico”.

Em suma, percebe-se nesses textos referentes ao binômio rural urbano, certa tendência a utilizar o termo cultura para designar a vida na cidade e expressões como costumes e tradições para referir-se ao vivido no campo. A hipótese de que o uso desses termos, numa perspectiva linear e de progresso, pode implicar a desvalorização das realidades locais e, principalmente, dos povos tradicionais se confirma em parte e precisa ser melhor testada. 


\section{NOTAS}

2 PESAVENTO, Sandra Jatay. História e História Cultural. Belo Horizonte: Autêntica, 2005, p. 19.

${ }^{3} \mathrm{O}$ conceito de romantismo é aplicado aqui aos historiadores que se lançaram na tarefa de escrever as histórias nacionais e àqueles que escreveram histórias locais para preenche-Ihes as lacunas. Pode ser aplicado, de forma geral, aos historiadores vinculados aos primeiros tempos dos Institutos HistóricoGeográficos. Tal romantismo não se caracterizaria, primordialmente, pelo bucolismo em relação ao mundo rural.

${ }^{4}$ O horizonte de compreensão, é o mundo da linguagem, o conjunto dos sentidos que nos são transmitidos e a partir do qual e no qual, nossa compreensão do mundo acontece. Ver, GADAMER, Hans-Georg. Verdad y metodo. 5.ed. Salamanca : Ed. Sígueme, 1993.

${ }^{5}$ A microrregião de Irati, cidade localizada a cerca de 150 quilômetros de Curitiba, compreende os municípios de Irati, Imbituva, Prudentópolis, Mallet, Teixeira Soares, Rebouças e Rio Azul

${ }^{6}$ Estudo desenvolvido a partir do convênio estabelecido entre o Governo Estadual e a Universidade Federal do Estado do Paraná, visando o incremento de políticas relativas ao triênio 1975-1978

7 ORREDA, José Maria. Irati 70 Anos. Irati: Impressora Martins, 1978, p.9.

${ }^{8}$ Id. Ibid. p.I.

9 CAMARGO, Geraldo Leão Veiga. Paranismo: arte, ideologia e relações sociais no Paraná. 1853 1953. Tese (Doutorado em História), Universidade Federal do Paraná, Curitiba, 2007, p.37.

10 Id. Ibid., p. 42.

" ORREDA, op. Cit., p.I.

12 Idem.

13 MARTINS, Romário. O brasão de Armas do Paraná e os seus symbolos... Apud, CORDOVA, Maria Julieta Weber. O paranismo e o processo de produção historiográfica paranaense: o episódio do cerco da Lapa. Revista de História Regional 12(2): I51-190, Inverno, 2007, p. I81.

${ }^{14}$ Davi Antônio da Silva Carneiro nasceu em Curitiba a 29 de março de 1904. Diplomado engenheiro pela Universidade Federal do Paraná, escreveu vários textos sobre a história do Paraná, principalmente, sobre o cerco da Lapa. Foi membro do Instituto Histórico, Geográfico e Etnológico Paranaense, e sócio correspondente do Instituto Histórico e Geográfico Brasileiro.

${ }^{15}$ José Maria Orreda nasceu em Irati a 27 de novembro de 1936. É formado em Educação Física, professor, pesquisador e escritor. Fundador e diretor do jornal $\bigcirc$ Debate. Co-idealizador do brasão e da bandeira de Irati/1967. Membro Fundador do Instituto Histórico, Geográfico e Etnográfico do Paraná.

${ }^{16}$ OLIVEIRA, Luis Cláudio Soares de. Joaquim contra o paranismo. 2005. Dissertação (Mestrado em Letras) - Universidade Federal do Paraná, Curitiba, 2005, p. 28.

17 CARNEIRO, Davi. História Psicológica do Paraná. Curitiba: Edição do Dr. Dicesar Plaisant, 1943, p.7.

${ }^{18}$ Id. Ibid..p. 34.

19 MACHADO, B. P. A historiografia de Romário Martins na sua "História do Paraná". In: COLÓQUIO DE ESTUDOS REGIONAIS, COMEMORATIVO DO I CENTENÁRIO DE ROMÁRIO MARTINS, 1974, Curitiba. Anais...Curitiba: UFPR, 1974, p.43.

${ }^{20}$ CARNEIRO, op. cit., p. 37.

${ }^{21}$ Idem.

${ }^{22}$ Estreita e alongada faixa de terras localizada no segundo planalto paranaense que se estende desde Jagaraiva até a margem do rio Negro, passando pela Lapa.

${ }^{23}$ CARNEIRO, op. cit., p. 37.

${ }^{24}$ Chama-se sistema de faxinais certo modo de utilização em comum das terras para a criação de animais, praticada na região centro sul do Paraná.

${ }^{25}$ CARNEIRO, op. cit, p. 39.

${ }^{26}$ Idem.

27 ORREDA, op. cit, p.2. 
${ }^{28}$ Foed Castro Chamma, nasceu em Irati-PR, a 31 de março de 1927. Reside no Rio de Janeiro desde $194 \mathrm{I}$ onde, além dos cursos fundamentais de $1^{\circ}$ e $2^{\circ}$ grau, fez estudo de línguas. $O$ primeiro livro, Melodias de estio (poesias), é de 1952/3, seguido de Iniciação ao sonho (1955), O poder da palavra (1959), Labirinto (1967) e Ir a ti (1969) entre outros.

${ }^{29}$ CHAMMA, Foed Castro. "Notas para um estudo da ecologia de Irati". Revista Irati - Sexagésimo aniversário do município. Irati, 1967. p. 37.

30 Id. Ibid. p. 35.

31 OLIVEIRA, cit. p. 40.

${ }^{32}$ Ver SEFFRIN, André. Palavra e labirinto. Jornal do Estado On Line. 09/07/200 I. s/p.

${ }^{33}$ OLIVEIRA, op. cit., p. 16

${ }^{34}$ CHAMMA, op. cit. p. 35

35 Id. Ibid. p. 37.

${ }^{36}$ Sobre a terra do futuro, ver OLIVEIRA, Luis Cláudio Soares de. Op. cit. (Cap. II).

37 CHAMMA, op. cit., p. 38.

${ }^{38}$ A Faculdade de Educação, Ciências e Letras de Irati foi criada pela Lei Municipal de n. 420, de 16 de julho de 1975. Foi reconhecida como Universidade - UNICENTRO - em agosto de 1997.

${ }^{39}$ CHAMMA, op. cit., p. 46.

${ }^{40}$ Id. Ibid. p. 93.

41 O programa dos "Clubes 4S" fora implantado, no Brasil, na década de 1960. As quatro consoantes "S" significavam: saber para sentir, saúde para servir. Inspirados nos "Clubes $4 \mathrm{H}$ ", criados nos anos de 1920 e 1930, nos Estados Unidos, tais clubes tinham como objetivo principal melhorar as condições sócio-econômicas de populações rurais, ou melhor, não urbanas. Seus membros desenvolviam trabaIhos de extensão rural, levando experiências e ensinamentos básicos a pequenos grupos de habitantes de regiões consideradas como carentes. Dedicavam-se, principalmente, a ensinar técnicas de economia doméstica, de higiene básica ou preventiva, de cooperativismo e de artesanato. A estratégica pedagógica consistia, basicamente, em promover competições de produtividade agropecuária.

${ }^{42}$ A mencionada deusa era também conhecida como Demeter, filha de Cronos e Réia. A principal narrativa cosmogônica a respeito de Ceres, talvez a mais disseminada, metaforiza o plantio e a colheita. Contava-se que desde o dia em que Hades levou-lhe a filha Perséfone para o reino subterrâneo, a deusa saíra alucinada, terra afora, tentando encontrá-la. Decidira não voltar para o Olimpo sem antes resgatar a filha. Durante o tempo em que permanecera longe da montanha dos deuses, a terra tornara-se estéril, o gado morrera e os grãos pararam de germinar. A população sofrera fome e doenças. Zeus, então, pedira a Hades que devolvesse Perséfone à mãe. Ele concordou, porém, obrigando a refém a comer um grão de romã. A ingestão da semente fazia parte de uma magia que obrigava quem o fizesse a retornar ao inferno, regularmente. Assim nasceram os mistérios da semeadura. Quando os grãos são enterrados, é Perséfone que vai ficar com Hades, com o nome de Proserpina. Quando os grãos brotam, é Perséfone, agora com o nome de Core, saindo da terra, para ficar um tempo junto à mãe. A história de Perséfone é interpretada como símbolo da morte e ressurreição nos mistérios de Elêusis, celebrados nos rituais gregos, prestados à Demeter.

${ }^{43}$ Deméter pode ser representada: sentada, com tochas ou uma serpente. Seus atributos são: o narciso e a espiga, seu pássaro é o grou, tendo numa das mãos a foice e noutra um punhado de espigas e papoulas.

${ }^{44} \mathrm{Na}$ Roma antiga, os rituais celebrados em louvor a essa divindade pertenciam ao festival Cereália, realizado durante a primavera. A deusa era personificada e celebrada por mulheres, em rituais secretos, no festival de Ambravália, realizado durante o mês de Maio. Existia um templo dedicado a Ceres no monte Aventino. O seu primeiro festival oficializado chamou-se Cereália (jogos de Ceres), instituído no século III a.C. e celebrados, anualmente, de 12 a 19 de abril. A veneração de Ceres ficou associada às classes plebéias, que dominavam o comércio de cereais. Filha de Cronos e Réia era servida por doze deuses menores que a assistiam, cada um deles responsável por certo aspecto da arte de lavrar a terra. ${ }^{45}$ Chama-se sistema de faxinal ${ }^{46}$ a certo modo de utilização das terras em comum, existente na região sul do Brasil. A área comum é destinada à criação de animais que são de propriedade particular. Vários 


\section{REVISTA ESBOÇOS Volume 16, № 21, pp. 181-206 - UFSC}

estudiosos do assunto consideram o sistema como acontecimento singular por causa de sua forma organizacional. Distingue-se tal sistema pelo uso coletivo de parte das terras enquanto que a porção destinada ao plantio é de uso particular. $\bigcirc$ caráter coletivo se manifesta, então, na forma de criadouro comum.

47 Distrito de Irati, colonizado por poloneses e ucranianos.

48 ORREDA, op. cit., p. $21-22$.

49 Ver CAMPIGOTO, José Adilçon e SOCHODOLAK, Hélio. Os faxinais na história da região das araucárias. In.: MOTTA, Márcia Menendes; OLINTO, Beatriz Anselmo; OLIVEIRA, Oséias de.(Orgs.) História agrária propriedade e conflito. Gurapuava, UNICENTRO, 2009. .

${ }^{50}$ Acadêmica do Curso de História da UNICENTRO, campus de Irati.

${ }^{51}$ Entrevista concedida por Vera Giocha, a Joceli Novak, em 30/10/2007.

${ }^{52} \mathrm{~A}$ região dos pinhais do segundo planalto paranaense é dividida em quatro zonas: Irati, Prudentópolis União da Vitória e Cândido de Abreu. Os municípios estudados pelo autor são: Irati, Teixeira Soares, Rebouças, Rio Azul, Antônio Olinto, São João do Triunfo, São Mateus do Sul, Prudentópolis, Ivaí e Imbituva. O escrito tornou-se livro em 197I, apresentando um capítulo sobre a terra, outro sobre o homem e outro em que aponta soluções aos problemas detectados.

${ }^{53}$ Cf. SPONHOLZ,Newton. A terra e o Homem no Sul do Paraná: problemas e perspectivas. Irati: Martins \& Abib, 1971, p. 39

${ }^{54}$ Id. Ibid. p. 40.

55 Id. Ibid. p. 41.

${ }^{56}$ Id. Ibid. p. 26

57 Id. Ibid. p. 27.

58 Id. Ibid. p. 30

59 Id. Ibid. pp. 34-35.

${ }^{60}$ Id. Ibid. p. 34.

${ }^{61}$ Sem realizar a destocagem da mata.

${ }^{62}$ As localidades de abrangência do distrito são: Cadeadinho, Cerro da Ponte Alta, Valeiros, Rio da Prata, Água Fria, Faxinal dos Luz, Vista Alegre, Faxinal dos Antônios, Água Mineral, Linha B, Faxinal dos Neves, Linha Irati, Linha Pinheiro Machado, Cadeado Santana, Cadeado Grande, Pinhal Preto, Campina Branca e outras. Como se vê, algumas das localidades ainda guardam o nome de Faxinal, mas provavelmente, boa parte delas funcionava, em épocas anteriores, neste mesmo sistema.

${ }^{63}$ FORNAZZARI, Lourival Luiz. "Investigações parasitológicas e sócio-econômicas". Revista O Debate, Irati: Martins \& Abib Ltda, $n^{\circ}$. I, ano I, 1968, p. 41.

${ }^{64}$ Id. Ibid. pp. 4I-42.

${ }^{65}$ Sobre o assunto, ver, MACHADO, Paulo Pinheiro. Lideranças do Contestado. Campinas, Ed. da UNICAMP, 2004.

${ }^{66}$ PEREIRA, Luiz Fernando Lopes. Paranismo: o Paraná inventado cultura e imaginário no Paraná da la República. 2. ed. Curitiba: Aos Quatro Ventos, 1998, p. 64.

${ }^{67}$ SPONHOLZ, op. cit. p. 3-4. 